\title{
EFFECT ON RUMEN MICROBIAL POPULATIONS OF AMMONIA TREATMENT OF RICE STRAW FORAGE FOR STEERS
}

\author{
HAJIME MINATO, ${ }^{*}$ SHIGENOBU ISHIZAKI, ${ }^{1}$ YOSHIKAZU ADACHI, \\ AND MAKOTO MITSUMORI \\ National Institute of Animal Health, Tsukuba, Ibaraki 305, Japan \\ ${ }^{1}$ Chiba Prefectural Livestock Experiment Station, Yachimata, Chiba 289-11, Japan
}

(Received April 5, 1989)

\begin{abstract}
The microbial populations and fermentation characteristics were compared in the rumina of two rumen-cannulated Holstein steers fed untreated rice straw (RS) and concentrate or ammonia-treated rice straw (ARS) and concentrate. The total volatile fatty acid concentrations in the rumina of both steers were significantly higher when they were fed ARS than when fed RS. The molar proportion of butyric acid when ARS was fed increased significantly, compared with the periods when was fed RS. The population density of protozoa varied only insignificantly with RS or ARS diets. But Dasytricha spp. increased with RS and Entodinium spp. increased with ARS. The viable counts of cellulolytic bacteria were higher with ARS than with RS. The viable counts of sulfate reducing bacteria were lower with ARS, compared with the RS diet. Feeding ARS increased the viable bacterial populations such as Eubacterium spp., Fibrobacter succinogenes, Ruminococcus albus, and Succinivibrio spp. But Bacteroides spp. and Butyrivibrio spp. were dominant when RS was fed.
\end{abstract}

Various physical and chemical treatments of low-quality roughages to improve their nutritive values for ruminants have been tried $(11,21)$. Such physical treatments as grinding, milling and chopping have increased the intake of roughages, but has not improved their nutritive value. Moreover, these treatments had the disadvantage of high costs. On the other hand, chemical treatment with calcium hydroxide, sodium hydroxide or ammonia has been tried to improve their nutritive values and to avoid spoilage during storage. Of the treatments with alkali, the ammonia treatment has the advantages of being relatively inexpensive, simply applied on the farm, and it increases the digestibility and the nitrogen content of the herbage. The

* Address reprint requests to: Dr. Hajime Minato, National Institute of Animal Health, 1-1, Kannondai 3-chome, Tsukuba, Ibaraki 305, Japan. 
treatment of herbage with ammonia has been extensively studied in Europe and Canada (27).

The improvement in digestion of alkali-treated straws has been attributed to the hydrolysis of linkage between lignin and other cell wall carbohydrates, saponification of bound acetic acid and phenolic acids, sweilling of cell walls, and the partial solubilization of hemicelluloses, lignin, protein and silica (11). It was reported that ammonia treatment increased the digestibility of barley straw by up to about $20 \%$ in cattle feeding experiments (28). Similar results in increased digestibility of herbages with ammonia treatment have been found by comparing the digestibility of untreated and ammonia-treated barley straw incubated with rumen contents in vitro or enclosed in nylon mesh bags placed in vivo rumen(9). Moreover, it was shown that ammonia treatment of barley straw increased its susceptibility to solubilization by the predominant cellulolytic bacteria from the rumen, Fibrobacter succinogenes, Ruminococcus albus and Ruminococcus flavefaciens $(5,16)$. However, a comparison of the constitution of ruminal micro-organisms between animals fed untreated and ammonia-treated straw has not yet been investigated. The aim of the present investigation was to clarify the influence of ammonia treatment of rice straw given to steers as a forage on the constitution of micro-organisms established in the rumen.

\section{MATERIALS AND METHODS}

Treatment of rice straw with anhydrous ammonia. Four hundred and fifty $\mathrm{kg}$ of rice straw were reconstituted to $30-40 \%$ moisture in tap water and piled on a large wooden draining board and wrapped with a $0.2-\mathrm{mm}$ thick vinyl sheet. About $15.5 \mathrm{~kg}$ of anhydrous $\mathrm{NH}_{3}$ was applied to the rice straw as $\mathrm{NH}_{3}$ gas. After being stored for 3 weeks, the ammonia-treated straw was opened, and dried outside in the sun. Treating the straw with $3.4 \%$ anhydrous ammonia increased the content of its crude protein 2.8 times, and its hemicellulose was reduced by $35.2 \%$ compared with untreated rice straw.

Animals, feeding and sampling regimen. Two Holstein steers, 14 months of age and weighing approximately $280 \mathrm{~kg}$, were used in this experiment. Each steer was fitted with a permanent cannula in the rumen before the start of the experiment. The composition of the control diet and two experimental diets are shown in Table 1. Rice straw and ammonia-treated rice straw, added as roughage in the experimental diets, were chopped into about $5 \mathrm{~cm}$ lengths with an electric cutter. At 9 a.m. and 4 p.m. each steer was fed a daily ration of concentrate and roughage divided into two equal parts. Mineral lick and water were available ad libitum. The experiment took place in the National Institute of Animal Health, beginning on May 22, 1986, and ending on November 20,1986. The rations were offered to two steers in the following sequence: for steer No. 1, 28 days of control (C)-diet, 28 days of ammonia-treated rice straw (ARS)-diet, 42 days of C-diet, 30 days of untreated rice straw (RS)-diet; for steer No. 2, 28 days of C-diet, 28 days of RS-diet, 42 days 
Table 1. Composition of rations fed to steers.

\begin{tabular}{lccc}
\hline \multicolumn{1}{c}{ Ingredient } & Control (C)-diet & $\begin{array}{c}\text { Untreated rice } \\
\text { straw (RS)-diet }\end{array}$ & $\begin{array}{c}\text { Ammonia-treated rice } \\
\text { straw (ARS)-diet }\end{array}$ \\
\hline Concentrate & $3 \mathrm{~kg}$ & $3 \mathrm{~kg}$ & $3 \mathrm{~kg}$ \\
Untreated rice straw & - & $4 \mathrm{~kg}$ & - \\
Ammonia-treated rice straw & - & - & $4 \mathrm{~kg}$ \\
Timothy hay & $2 \mathrm{~kg}$ & - & - \\
Alfalfa hay cubes & $1 \mathrm{~kg}$ & - & - \\
\hline
\end{tabular}

of C-diet, 30 days of ARS-diet. The adaptation period from a preceding diet to a next diet was a week and roughage only in the diet was changed gradually during this period. Samples of rumen content, which contained solids and liquid, were collected through the rumen cannula before morning feeding on the 21 st day of each feeding period.

Sample preparation. Immediately after each sample collection, the rumen contents were transported to a laboratory. Two hundred grams of the rumen content, containing equal weights of solids and liquid portions, were processed under a stream of oxygen-free $\mathrm{CO}_{2}$ for $1 \mathrm{~min}$ with a homogenizer (Nihon Seiki Manufacturing Ltd., Tokyo; Model Ace), and the 1 min homogenizing treatment was repeated once more after halting the machine for $1 \mathrm{~min}$. Then the homogenized rumen content was strained through one layer of gauze.

A portion of the strained rumen fluid was used to enumerate viable rumen bacteria. Another portion was blended with an equal volume of saline solution containing $20 \%$ formalin $(\mathrm{v} / \mathrm{v})$, for total bacterial enumeration by microscopic examination.

The remaining portion of the strained rumen fluid was stored in a refrigerator following acidification with $24 \%(\mathrm{w} / \mathrm{v})$ meta-phosphoric acid in $5 \mathrm{~N}_{2} \mathrm{SO}_{4}$, for volatile fatty acid (VFA) analysis, or for non-VFA analysis such as lactic acid or succinic acid. After centrifuging, the VFA in samples was analyzed by gas chromatography by the method of Packett and McCune(22), and non-VFA was analyzed by the method of Holdeman et al. (12). The concentration of VFA and non-VFA in the samples was determined using respectively 2-methyl-valeric acid and fumaric acid as internal standards.

Enumeration of bacteria. For anaerobic bacterial enumeration, ten fold serial dilutions of the strained rumen fluid were made in the anaerobic dilution solution of Bryant and Burkey (2), to which agar was added to $0.1 \%(\mathrm{w} / \mathrm{v})$. Three sets of tubes containing agar medium or liquid medium were inoculated with $0.2 \mathrm{ml}$ from each of the appropriate dilutions.

Total viable counts of bacteria in the strained rumen fluid were made by the techniques of Hungate (14) with the rumen fluid-glucose-cellobiose-maltose-starchagar medium (RGCMSA) identical to the complete medium of Scott and Dehority (25) except for the carbohydrates. Colonies in the roll tubes were counted 
after a 5-day incubation period at $38^{\circ} \mathrm{C}$, and the viable count was taken as the average of the three roll-tube counts at the appropriate dilution.

Viable counts of the following functional groups of bacteria were made: cellulolytic bacteria, amylolytic bacteria, xylan-fermenters and pectin-fermenters. The basal medium to prepare the liquid media used for enumerating those bacteria contained ingredients in the following percentages: mineral solution $\mathrm{A}(0.6 \%$ $\left.\mathrm{K}_{2} \mathrm{HPO}_{4}\right)$, 7.5; mineral solution B $\left(0.6 \% \mathrm{KH}_{2} \mathrm{PO}_{4}, 1.2 \%\left(\mathrm{NH}_{4}\right)_{2} \mathrm{SO}_{4}, 1.2 \%\right.$ $\mathrm{NaCl}, 0.12 \% \mathrm{MgSO}_{4} \cdot 7 \mathrm{H}_{2} \mathrm{O}, 0.12 \% \mathrm{CaCl}_{2} \cdot 2 \mathrm{H}_{2} \mathrm{O}$ ), 7.5; sodium resazurin, 0.0001; trypticase (BBL Microbiology Systems, Cockeeysville, MD), 0.5 (or 0.2 for cellulolytic bacteria); clarified rumen liquor, 30; sodium carbonate, 0.4 (or 0.06 for the xylan- or pectin-decomposing bacteria); L-cysteine- $\mathrm{HCl} \cdot \mathrm{H}_{2} \mathrm{O}, 0.05$. Cellulolytic bacteria were enumerated with the basal medium supplemented with $0.12 \%$ yeast extract, a strip of Toyo No. 2 filter paper and $0.02 \%$ cellobiose (18). Amylolytic bacteria were enumerated with the basal medium supplemented with $0.1 \%$ soluble starch (Difco Laboratories, Detroit, MI). Starch hydrolysis was detected by the addition of iodine solution to the cultures after a 5-day incubation period at $38^{\circ} \mathrm{C}$. Xylan-fermenters were enumerated in the basal medium supplemented with $0.5 \%$ xylan (Aldrich Chemical Company, Inc., Milwaukee, Wis.) from oat spelts. Pectin-fermenters were enumerated with the basal medium supplemented with $0.5 \%$ pectin (Wako Pure Chemical Industries, Ltd., Tokyo) from citrus. The gas phase in the liquid media for enumerating xylan- or pectin-fermenters was $10 \% \mathrm{CO}_{2}-90 \% \quad \mathrm{~N}_{2}$. The presence of xylan- or pectinfermenters was determined by measuring the $\mathrm{pH}$ of the cultures with a $\mathrm{pH}$ meter after a one-week incubation period at $38^{\circ} \mathrm{C}$. Sulfate-reducing bacteria were enumerated with the liquid medium of Butlin et al. (4), to which $10 \%$ clarified rumen liquor, $0.1 \%$ yeast extract (Difco), $0.0001 \%$ sodium resazurin, $0.01 \%$ sodium thioglycolate and $0.01 \% \mathrm{~L}$-ascorbic acid were supplemented. The gas phase of the medium was $100 \% \mathrm{CO}_{2}$. The presence of sulfate-reducing bacteria was determined by the appearance of black color in the cultures after a one-week incubation period at $38^{\circ} \mathrm{C}$. In the liquid culture, the count of each functional group of bacteria was taken as the most probable number (MPN). Methanogens were enumerated with the liquid medium of Paynter and Hungate (23), supplemented with $0.2 \%$ sodium formate. The methanogens and preparation of the medium were cultured using a high pressure- $\mathrm{O}_{2}$ free gas injection device (Sanshin Industrial Co., Ltd., Yokohama) according to the method described by Balch et al. (1). The presence of methanogens was determined by the detection of methane in the gas phase after a three-week incubation period at $38^{\circ} \mathrm{C}$. Methane was determined by using a GC-8A gas chromatograph (Shimadzu Corp., Kyoto), equipped with a thermal conductivity detector and fitted with a column of molecular sieve (5A, 60 to 80 mesh; Guild Corp., Bethel Park, Pa.) operated at $50^{\circ} \mathrm{C}$. Total counts of bacteria in the strained rumen fluid were carried out according to the method described by Minato and Suto $(19,20)$.

Primary identification of rumen bacteria isolated. Approximately 35 strains 
were isolated by picking colonies at random from roll tubes used in the total viable count containing 20-50 colonies per tube. After confirming the purity of all strains isolated, they were examined for their morphological and biochemical characteristics. Tests for their gram reaction, motility, oxygen relation, $\mathrm{H}_{2} \mathrm{~S}$ production, carbohydrates fermentation (glucose, maltose, cellobiose, xylose, xylan and pectin), and milk coagulation or peptonization, were performed as described by Bryant et al. (3). Tests for their starch hydrolysis and cellulose digestion were made as described above. Organic acids such as VFA and non-VFA produced from carbohydrates were analyzed using a gas chromatograph as described above. Primary identification of bacterial isolates was carried out according to the VPI Manual (12) and Bergey's Manual of Systematic Bacteriology $(17,26)$.

Enumeration of protozoa. A liquid portion of rumen content was blended with an equal volume of saline solution containing $20 \%$ formalin $(\mathrm{v} / \mathrm{v})$. A portion of the sample fixed with formalin was stained with staining solution containing $0.05 \%$ methylgreen in $10 \%$ formal saline. The protozoa in the samples were counted and identified using a plankton counter deck glass as described by Imai and Katsuno (15).

Statistical analyses. Data were subjected to analysis of variance and compared with $\mathrm{F}$ tests.

\section{RESULTS}

Relationship between VFA concentrations and proportions in the rumen contents and diets

VFA concentrations and proportions in the rumen of steers at the periods of sampling for the estimation of the microflora are presented in Table 2. The total VFA concentrations in the rumina of both steers fed C-diet were affected not only by the periods of sampling but also by individual steers. On the other hand, the molar proportion of VFA in the rumina of the two steers fed C-diet were relatively similar. Total VFA concentrations in the rumina of both steers fed ARS-diet were significantly $(p<0.2)$ higher than when fed RS-diet. The molar proportion of butyric acid in the rumen of both steers fed ARS-diet increased significantly $(p<0.1)$, compared with the periods of feeding the RS-diet.

\section{Influence of diets on protozoal population}

The two steers had the same protozoa genera, except Diplodinium spp. which was absent in steer No. 1. The total numbers and constitution of protozoa in the rumen of steers are shown in Table 3. The total numbers of protozoa were not affected by individual steers. But the protozoal constitution was significantly affected by feeds. The proportion of Dasytricha spp. was higher $(p<0.1)$ in feeding RS-diet than in feeding ARS-diet. And, the proportion of Entodinium spp. was higher $(p<0.1)$ in feeding C-diet than in feeding ARS- or RS-diet. 
Table 2. Concentration and composition of VFA in the rumina of steers fed different diets.

\begin{tabular}{|c|c|c|c|c|c|c|}
\hline & \multirow{3}{*}{ C-diet } & \multirow{3}{*}{ ARS-diet } & \multirow{3}{*}{ RS-diet } & \multicolumn{3}{|c|}{$F$ test } \\
\hline & & & & \multicolumn{2}{|c|}{ Diet } & \multirow{2}{*}{ Animal } \\
\hline & & & & $\mathrm{C}:(\mathrm{ARS}+\mathrm{RS})$ & ARS : RS & \\
\hline \multicolumn{7}{|l|}{ Total VFA } \\
\hline \multicolumn{7}{|c|}{ VFA composition $(\mathrm{mol} \%)^{a}$} \\
\hline Acetic acid & $68.6 \pm 1.1$ & $66.5 \pm 0.7$ & $67.5 \pm 1.1$ & 1.2 & 0.2 & $5.1^{\circ}$ \\
\hline Propionic acid & $10.8 \pm 0.5$ & $13.8 \pm 1.2$ & $13.4 \pm 1.0$ & $5.1^{\circ}$ & 0.2 & 2.0 \\
\hline Isobutyric acid & $1.7 \pm 0$ & $1.0 \pm 0$ & $1.4 \pm 0$ & $88.2^{* *}$ & $19.6^{* *}$ & 0.2 \\
\hline Butyric acid & $15.4 \pm 1.1$ & $15.8 \pm 1.1$ & $13.4 \pm 0.9$ & 2.1 & $9.3^{*}$ & 0 \\
\hline Isovaleric acid & $2.2 \pm 0.1$ & $1.5 \pm 0.2$ & $1.9 \pm 0.1$ & $8.8^{*}$ & 2.0 & 1.6 \\
\hline Valeric acid & $1.0 \pm 0.1$ & $1.0 \pm 0.3$ & $0.6 \pm 0.2$ & 0.2 & 0.4 & 1.1 \\
\hline Caproic acid & $0.4 \pm 0.1$ & $0.3 \pm 0.1$ & $0.2 \pm 0.1$ & 0.5 & 0.3 & 1.2 \\
\hline
\end{tabular}

VFA: volatile fatty acids. ${ }^{\circ} p<0.1,{ }^{*} p<0.05,{ }^{* *} p<0.01$. For C-diet, RS-diet and ARS-diet, see Table 1 .

${ }^{a}$ Mean and standard error of the mean. Each mean in the C-diet column is based on four determinations, and on two determinations in the ARS of RS-diet column.

Table 3. Total count and generic constitution of protozoa in the rumina of steers fed different diets.

\begin{tabular}{|c|c|c|c|c|c|c|}
\hline & \multirow{3}{*}{ C-diet } & \multirow{3}{*}{ ARS-diet } & \multirow{3}{*}{ RS-diet } & \multicolumn{3}{|c|}{$F$ test } \\
\hline & & & & \multicolumn{2}{|l|}{ Diet } & \multirow{2}{*}{ Anima } \\
\hline & & & & $\mathrm{C}:(\mathrm{ARS}+\mathrm{RS})$ & ARS : RS & \\
\hline \multicolumn{7}{|l|}{ Total count } \\
\hline $\begin{array}{l}\text { (Log No./g rumen } \\
\text { content })^{a}\end{array}$ & $5.9 \pm 0.1$ & $5.6 \pm 0.3$ & $5.6 \pm 0.3$ & 1.6 & 0 & 0 \\
\hline \multicolumn{7}{|c|}{ Constitution of protozoa $(\%)^{a}$} \\
\hline Dasytricha spp. & $6.4 \pm 2.9$ & $1.2 \pm 0.1$ & $14.1 \pm 1.4$ & 0.1 & $4.7^{\circ}$ & 0.4 \\
\hline Isotricha spp. & $2.0 \pm 1.0$ & $1.6 \pm 0.4$ & $4.3 \pm 1.0$ & 0.4 & 1.4 & 0.1 \\
\hline Entodinium spp. & $63.9 \pm 7.0$ & $58.6 \pm 1.8$ & $36.1 \pm 3.8$ & $5.4^{\circ}$ & 2.3 & 0.2 \\
\hline Epidinium spp. & $11.7 \pm 1.8$ & $15.1 \pm 4.0$ & $17.6 \pm 1.7$ & 1.4 & 0.2 & 0.2 \\
\hline Eremoplastron spp. & $11.8 \pm 5.6$ & $19.0 \pm 2.9$ & $24.8 \pm 2.2$ & 1.5 & 0.5 & 0 \\
\hline Eudiplodinium spp. & $0.7 \pm 0.3$ & $4.1 \pm 0.7$ & $1.1 \pm 0.7$ & $4.5^{\circ}$ & 1.0 & 0 \\
\hline Eodinium spp. & 0 & $0.6 \pm 0.4$ & $2.2 \pm 1.5$ & 1.4 & 1.0 & 0.5 \\
\hline Diplodinium spp. & $3.2 \pm 2.7$ & 0 & 0 & 0.7 & 0 & 0.7 \\
\hline
\end{tabular}

${ }^{\circ} p<0.1,{ }^{*} p<0.05,{ }^{* *} p<0.01$. For C-diet, RS-diet and ARS-diet, see Table 1.

${ }^{a}$ Mean and standard error of the mean. Each mean in the C-diet column is based on four determinations, and on two determinations in the ARS or RS-diet column. 
Table 4. Total count of bacteria and viable count of some bacteria in the rumina of steers fed different diets.

\begin{tabular}{|c|c|c|c|c|c|c|}
\hline & \multirow{3}{*}{ C-diet } & \multirow{3}{*}{ ARS-diet } & \multirow{3}{*}{ RS-diet } & \multicolumn{3}{|c|}{$F$ test } \\
\hline & & & & \multicolumn{2}{|c|}{ Diet } & \multirow{2}{*}{ Animal } \\
\hline & & & & $C:(\mathrm{ARS}+\mathrm{RS})$ & ARS : RS & \\
\hline $\begin{array}{l}\text { Total count } \\
\qquad \begin{array}{l}\text { (Log No./g rumen } \\
\text { content })^{a}\end{array}\end{array}$ & $10.5 \pm 0.1$ & $10.9 \pm 0.1$ & $10.3 \pm 0.2$ & 2.1 & 0.1 & 0 \\
\hline \multicolumn{7}{|l|}{$\begin{array}{l}\text { Viable count of some bacteria } \\
\quad(\text { Log No./g rumen content })^{a}\end{array}$} \\
\hline Total viable count & $9.3 \pm 0.1$ & $9.3 \pm 0.2$ & $9.1 \pm 0.2$ & 0.1 & 0.4 & 0 \\
\hline Cellulolytic bacteria & $8.0 \pm 0.1$ & $8.2 \pm 0.2$ & $7.3 \pm 0.1$ & 1.3 & $7.4^{\circ}$ & 0.1 \\
\hline Methanogens & $7.3 \pm 0.1$ & $7.7 \pm 0.3$ & $7.5 \pm 0$ & 1.5 & 0.2 & 2.8 \\
\hline Sulfate reducing bacteria & $6.7 \pm 0.1$ & $5.9 \pm 0$ & $6.6 \pm 0.1$ & $5.1^{\circ}$ & $6.7^{\circ}$ & 0.3 \\
\hline Amylolytic bacteria & $9.6 \pm 0.1$ & 9.4 & 9.4 & 0.1 & 0.3 & 0.1 \\
\hline Xylan fermenters & $\mathrm{NC}$ & 9.7 & 9.4 & & & \\
\hline Pectin fermenters & $\mathrm{NC}$ & 9.1 & 9.1 & & & \\
\hline
\end{tabular}

${ }^{\circ} p<0.1,{ }^{*} p<0.05,{ }^{* *} p<0.01 . \mathrm{NC}=$ not counted. For C-diet, RS-diet and ARS-diet, see Table 1.

${ }^{a}$ Mean and standard error of the mean. Each mean in the C-diet column is based on four counts, and on two counts in the ARS or RS-diet column.

\section{Influence of diets on viable count of some bacteria}

Total counts of bacteria and viable counts of some bacteria in the rumen ofs steers at the periods of feeding different diets are shown in Table 4.

Total counts of bacteria and viable counts of some bacteria were higher in September than in June in feeding the same C-diet. For all samples examined, the total counts of bacteria by direct microscopic observation were clearly higher than the total viable counts. This suggests that a number of rumen bacteria did not make a colony on the RGCMSA medium.

On the other hand, viable counts of a given functional group of bacteria were affected by diets. The viable counts of cellulolytic bacteria were higher $(p<0.1)$ in feeding ARS-diet than in feeding RS-diet. Contrary to this, the viable counts of sulfate reducing bacteria decreased in feeding ARS-diet, compared with feeding RS-diet $(p<0.1)$. The viable counts of methanogens were not changed by feeding different diets. The viable counts of amylolytic bacteria, pectin-fermenters and xylan-fermenters was at the level of $10^{9}$.

\section{Influence of diets on the constitution of rumen microflora}

The constitutions of predominant bacteria isolated from the rumen contents of both steers at the periods of feeding different diets are presented in Table 5. The constitutions of rumen microflora of both steers fed the same C-diet were different to a certain degree between two seasons. In June, the viable bacterial population 
Table 5. The constitution of bacteria isolated at high dilutions from the rumen content of steers fed different diets.

\begin{tabular}{|c|c|c|c|c|c|c|}
\hline & \multirow{3}{*}{$\begin{array}{c}\text { C-diet } \\
(\%)\end{array}$} & \multirow{3}{*}{$\begin{array}{l}\text { ARS-diet } \\
(\%)\end{array}$} & \multirow{3}{*}{$\begin{array}{l}\text { RS-diet } \\
(\%)\end{array}$} & \multicolumn{3}{|c|}{$F$ test } \\
\hline & & & & \multicolumn{2}{|l|}{ Diet } & \multirow{2}{*}{ Animal } \\
\hline & & & & $C:(A R S+R S)$ & ARS : RS & \\
\hline Bacteroides spp. & $22.7 \pm 7.8^{a}$ & $16.5 \pm 5.6$ & $53.5 \pm 0$ & 0.1 & 0.3 & 0.1 \\
\hline Ruminobacter amylophilus & $1.0 \pm 0.8$ & $3.7 \pm 2.6$ & $1.8 \pm 1.3$ & 0.6 & 0.3 & 0 \\
\hline Fibrobacter succinogenes & $0.8 \pm 0.7$ & $2.5 \pm 1.7$ & 0 & 0.1 & 1.3 & 0.1 \\
\hline Selenomonas spp. & $13.0 \pm 5.1$ & $1.2 \pm 0.8$ & 0 & 3.0 & 0.1 & 0.1 \\
\hline Succinivibrio spp. & 0 & $3.9 \pm 0.7$ & 0 & 1.9 & 3.7 & 0.1 \\
\hline Fusobacterium spp. & $5.7 \pm 1.3$ & $2.6 \pm 0.1$ & $5.4 \pm 1.2$ & 0.8 & 1.0 & 2.4 \\
\hline Butyrivibrio spp. & $35.2 \pm 5.1$ & $23.9 \pm 1.3$ & $32.2 \pm 2.5$ & 0.9 & 0.6 & 2.1 \\
\hline Ruminococcus spp. & $4.4 \pm 2.1$ & $1.2 \pm 0.9$ & 0 & 1.6 & 0.1 & 0.5 \\
\hline Ruminococcus albus & $0.8 \pm 0.7$ & $2.9 \pm 2.0$ & 0 & 0.1 & 1.4 & 0.1 \\
\hline Eubacterium spp. & $3.2 \pm 1.1$ & $30.2 \pm 11.0$ & $5.4 \pm 1.2$ & 3.3 & $4.8^{\circ}$ & 0.8 \\
\hline Clostridium spp. & $1.6 \pm 0.8$ & $2.5 \pm 1.7$ & 0 & 0.1 & 1.1 & 0.6 \\
\hline Streptococcus spp. & $3.2 \pm 1.3$ & $2.6 \pm 0.1$ & $3.6 \pm 2.5$ & 0.1 & 0.1 & 0.2 \\
\hline Lactobacillus spp. & $1.6 \pm 1.3$ & 0 & 0 & 0.7 & 0 & 0.7 \\
\hline Unidentified bacteria & $6.9 \pm 2.4$ & $6.5 \pm 0.6$ & $7.2 \pm 2.5$ & 0.1 & 0.1 & 0.1 \\
\hline
\end{tabular}

${ }^{\circ} p<0.1,{ }^{*} p<0.05,{ }^{* *} p<0.01$. For C-diet, RS-diet and ARS-diet, see Table 1.

a Figures show the mean and standard error of the mean. Each mean in the C-diet column is based on four determinations, and on two determinations in the ARS or RS-diet column.

in feeding C-diet was dominated by Butyrivibrio spp. and Selenomonas spp. but the population was predominantly Butyrivibrio spp. and Bacteroides spp. in September. In spite of this, the constitutions of rumen microflora of both steers fed the same diet such as ARS or RS-diet at the different periods were similar. Clearly, the constitutions were affected by diets. The viable bacterial population in the rumen of both steers fed ARS-diet was dominated by Eubacterium spp., Butyrivibrio spp. and Bacteroides spp. On the other hand, the bacterial population in feeding RS-diet was dominated by Bacteroides spp. and Butyrivibrio spp. Feeding ARS-diet significantly increased $(p<0.1)$ the viable count of Eubacterium spp., compared with RS-diet. Eubacterium spp. was present at 3.1-7.1\% of the bacterial population with RS-diet or C-diet. The cellulolytic bacteria such as $F$. succinogenes and $R$. albus were predominant with ARS-diet, but was not detected at high dilutions of the rumen contents of either steer with RS-diet. Fusobacterium spp. remained a small but constant proportion of the microflora with three different diets. Ruminobacter amylophilus was detected in the rumen of both steers at the sampling period of November 8, independently of the diets. Streptococcus spp. was present at $2.4-7.1 \%$ of the bacterial population in the rumen of one steer on three different diets.

\section{Utilization of polysaccharides by bacteria isolated from the rumen}

The starch-, xylan- and pectin-digesting ability of the predominant bacteria 
Table 6. Utilization of polysaccharides by bacteria isolated at high dilutions from the rumen content of steers.

\begin{tabular}{lcccc}
\hline \multicolumn{1}{c}{ Bacteria } & $\begin{array}{c}\text { Starch } \\
\text { fermenters }\end{array}$ & $\begin{array}{c}\text { Xylan } \\
\text { fermenters }\end{array}$ & $\begin{array}{c}\text { Pectin } \\
\text { fermenters }\end{array}$ & $\begin{array}{c}\text { Total number of } \\
\text { strains examined }\end{array}$ \\
\hline Bacteroides spp. & $74.2^{a}$ & 74.2 & 86.4 & 66 \\
Ruminobacter amylophilus & 100 & 0 & 0 & 5 \\
Fibrobacter succinogenes & 0 & 0 & 66.6 & 3 \\
Selenomonas spp. & 56.3 & 31.2 & 87.5 & 16 \\
Succinivibrio spp. & 33.3 & 0 & 66.6 & 3 \\
Fusobacterium spp. & 58.3 & 41.6 & 100 & 12 \\
Butyrivibrio spp. & 50.6 & 63.3 & 100 & 79 \\
Ruminococcus spp. & 0 & 16.6 & 66.6 & 6 \\
Ruminococcus albus & 0 & 66.6 & 33.3 & 3 \\
Eubacterium spp. & 13.8 & 93.1 & 24.1 & 29 \\
Clostridium spp. & 0 & 50 & 50 & 4 \\
Streptococcus spp. & 100 & 0 & 100 & 8 \\
Lactobacillus spp. & 0 & 50 & 50 & 2 \\
\hline
\end{tabular}

${ }^{a}$ Figures show the percentage of strains of each bacterial group which digested the carbohydrates indicated.

isolated from the rumina in this investigation is presented in Table 6. Many strains of Butyrivibrio spp., Bacteroides spp., Selenomonas spp. and Fusobacterium spp. were able to digest starch, xylan and pectin. Almost all strains of Eubacterium spp., a butyric acid producer, digested xylan, but strains capable of digesting starch and pectin were very limited. The cellulolytic $F$. succinogenes strains did not digest starch and xylan. Other cellulolytic $R$. albus strains did not digest starch. The amylolytic $R$. amylophilus strains did not digest xylan and pectin. Some strains of Succinivibrio spp. and Streptococcus spp. digested pectin and starch.

\section{DISCUSSION}

The total bacterial cell count, total viable count and constitution of bacteria in the rumen of the same steer fed C-diet containing timothy hay, alfalfa hay cubes and concentrate, varied at the two sampling months. The variations in the bacterial population density and the protozoal population density in the rumen contents of both steers agreed well with the principle that in the absence of protozoa there is frequently a compensatory rise in the number of bacteria (8). Furthermore, the predominant bacteria in the rumen contents in the two steers fed C-diet were somewhat different at the two sampling months. This suggests that there are some monthly or seasonal variations in the constitution of rumen bacteria in steers fed on the same ration.

Although the constitution of rumen microflora apparently changed with time, the kinds of the predominant bacteria established in the rumina of both steers in the periods of feeding the same diet were quite similar regardless of sampling months, 
whether untreated or ammonia-treated rice straw was fed. And more kinds of bacteria were isolated at high dilutions from the rumen contents of both steers fed ARS-diet than in feeding RS-diet. The viable counts of cellulolytic bacteria were higher in feeding ARS-diet than in feeding RS-diet. The cellulolytic bacteria such as $F$. succinogenes and $R$. albus were isolated at high dilutions from the rumen contents of both steers fed ARS-diet, but were not isolated in feeding RS-diet (Table 5). These results were supported by the findings that treatment of barley straw with anhydrous ammonia increased its digestion by $F$. succinogenes and $R$. albus in vitro (16) and ammonia-treatment of barley straw increased microbial colonization on straw (24). However, the kind of cellulolytic bacteria isolated at high dilutions varied with steers. $R$. albus and $F$. succinogenes were isolated at high dilutions from the rumen contents of steer No. 1 and No. 2, respectively. It would appear, therefore, that $R$. albus and $F$. succinogenes must be responsible for most of the cellulolytic activity in the rumina of these steers. The proportions of Butyrivibrio spp. among bacteria isolated were relatively similar in the four diet periods for each steer. None of the butyrivibrio strain isolated in this investigation were cellulolytic. Eubacterium spp. constituted a large proportion of the ruminal bacterial population of both steers in the period of feeding ARS-diet (Table 5). The increase of Eubacterium spp. in feeding ARS-diet can be explained by the fact that ammonia treatment broke down the partial linkages between lignin and other cell wall carbohydrates of the straw, so these bacteria gained easy access to xylan and other carbohydrates of the cell wall carbohydrates.

The constitution of protozoa in the rumen contents of both steers varied in the different diet periods. The proportion of Dasytricha spp. in the protozoal population increased with RS-diet compared with the ARS-diet. This agrees with the report that Isotrichids became abundant in ruminants fed hay rich in soluble sugars (13). While, Dasytricha spp. decreased with the ARS-diet (Table 3). The decrease in the numbers of Dasytricha spp. may have been due to partial losses of some soluble sugars from the straw during the treatment with ammonia. It has been reported that ruminal protozoal populations can be divided into three groups: type A, characterized by the presence of Polyplastron spp., Diploplastron spp. and Ophryoscolex spp.; type B, characterized by Epidinum spp., Eudiplodinium spp. and Eremoplastron spp.; common type, characterized by Isotricha spp., Dasytricha spp. and Entodinium spp., which coexist satisfactorily in either type A or type B populations $(6,7)$. Both steers used in this investigation had a type B populations. And feeding ARS-diet did not affect the establishment of type A or type B population.

The concentrations of VFA in the rumen contents of both steers were significantly higher with ARS-diet than RS-diet (Table 2). This may be related to the findings that the treatment of straw with ammonia increased its susceptibility to solubilization, the production of microbial protein, and fermentation products by the rumen cellulolytic bacteria (16) and by mixed rumen micro-organisms (10). The composition of VFA in the rumen contents of both steers fed ARS-diet was 
characterized by an increased proportion of butyric acid, compared with the period of feeding RS-diet. Butyric acid is produced in vitro by a relatively few kinds of rumen bacteria, the common one being Butyrivibrio spp. However, these bacteria did not increase particularly with the ARS-diet, compared with the RS-diet while the other butyric acid-producing bacteria, Eubacterium spp., increased significantly with the ARS-diet (Table 5). Therefore, the metabolism of Eubacterium spp. must contribute significantly to the butyric acid production in the rumen contents of both steers. The proportion of acetic acid in the VFA of the rumen contents of both steers was very high in each diet period. Acetic acid is produced in vitro by many kinds of rumen bacteria and protozoa. Therefore, it is probable that most of the flora and fauna in the rumen contents of both steers had a considerable capacity to produce acetic acid.

In conclusion, the treatment of rice straw with ammonia improved its digestibility by rumen micro-organisms, increased the intake by cattle, and improved cattle productivity.

The numbers of sulfate reducing bacteria in the rumen contents of both steers were significantly higher with the RS-diet than with the ARS-diet (Table 4). Dissection of both animal bodies after this experiment was finished revealed that the color of the rumen epithelium of the steer on the ARS-diet was faintly brown, while that of the steer on the RS-diet was black. A problem for the future is whether there is a relationship between the numbers of ruminal sulfate-reducing bacteria and the color of rumen epithelium.

\section{REFERENCES}

1) Balch, W. E., Fox, G. E., Magrum, L. J., Woese, C. R., and Wolfe, R. S., Methanogens: Reevaluation of a unique biological group. Microbiol. Rev., 43, 260-296 (1979).

2) Bryant, M. P. and Burkey, L. A., Cultural methods and some characteristics of some of the more numerous groups of bacteria in the bovine rumen. J. Dairy Sci., 36, 205-217 (1953).

3) Bryant, M. P., Small, N., Bouma, C., and Chu, H., Bacteroides ruminicola $\mathrm{n}$. sp. and Succinimonas amylolytica - the new genus and species. J. Bacteriol., 76, 15-23 (1958).

4) Butlin, K. R., Adams, M. E., and Thomas, M., The isolation and cultivation of sulphate-reducing bacteria. J. Gen. Microbiol., 3, 46-59 (1949).

5) Cheng, K. J., Stewart, C. S., Dinsdale, D., and Costerton, J. W., Electron microscopy of bacteria involved in the digestion of plant cell walls. Anim. Feed Sci. Technol., 10, 93-120 (1984).

6) Eadie, J. M., The development of rumen microbial populations in lambs and calves under various conditions of management. J. Gen. Microbiol., 29, 563-578 (1962).

7) Eadie, J. M., Studies on the ecology of certain rumen ciliate protozoa. J. Gen. Microbiol., 49, 175-194 (1967).

8) Eadie, J. M. and Hobson, P. N., Effect of the presence or absence of rumen ciliate protozoa on the total rumen bacterial count in lambs. Nature, 193, 503-505 (1962).

9) Graham, H. and $\AA$ man, P., A comparison between degradation in vitro and in sacco of constituents of untreated and ammonia-treated barley straw. Anim. Feed Sci. Technol., 10, 199-211 (1984).

10) Graham, H., Åman, P., Theander, O., Kolankaya, N., and Stewart, C. S., Influence of heat sterilization and ammoniation on straw composition and degradation by pure cultures of cellulolytic rumen bacteria. Anim. Feed Sci. Technol., 12, 195-203 (1985). 
11) Hartley, R. D., Chemical constitution, properties and processing of lignocellulosic wastes in relation to nutritional quality for animals. Agric. Environ., 6, 91-113 (1981).

12) Holdeman, L. V., Cato, E. P., and Moore, W. E. C., Anaerobe Laboratory Manual, 4th ed., V.P.I., Blacksburg, Virginia (1977), p. 13-135.

13) Hungate, R. E., The Rumen and Its Microbes: Nutrition and Growth, Academic Press, New York (1966), p. 125-136.

14) Hungate, R. E., A roll tube method for cultivation of strict anaerobes. In Methods in Microbiology 3B, ed. by Norris, J. R. and Ribbons, D. W., Academic Press, London (1969), p. 117-132.

15) Imai, S. and Katsuno, M., Rūmen senmōchū no dōtei no tebiki (A guide to identification of rumen ciliate protozoa) (in Japanese). Miyajukaishi, 30, 3-24 (1977).

16) Kolankaya, N., Stewart, C. S., Duncan, D. H., Cheng, K. J., and Costerton, J. W., The effect of ammonia treatment on the solubilization of straw and the growth of cellulolytic rumen bacteria. J. Appl. Bacteriol., 58, 371-379 (1985).

17) Krieg, N. R. and Holt, J. G., Bergey's Manual of Systematic Bacteriology, Vol. 1, The Williams and Wilkins Co., Baltimore (1984), p. 38-685.

18) Mann, S. O., An improved method for determining cellulolytic activity in anaerobic bacteria. $J$. Appl. Bacteriol., 31, 241-244 (1968).

19) Minato, H. and Suto, T., Technique for fractionation of bacteria in rumen microbial ecosystem. I. Attachment of rumen bacteria to starch granules and elution of bacteria attached to them. $J$. Gen. Appl. Microbiol., 22, 259-276 (1976).

20) Minato, H. and Suto, T., Technique for fractionation of bacteria in rumen microbial ecosystem. IV. Attachment of rumen bacteria to cellulose powder and elution of bacteria attached to it. $J$. Gen. Appl. Microbiol., 27, 21-31 (1981).

21) Owen, E., Processing of roughages. In Recent Advances in Animal Nutrition, ed. by Haresign, W. and Lewis, D., Butterworths, London (1978), p. 127-148.

22) Packett, L. V. and McCune, R. W., Determination of steam-volatile organic acids in fermentation media by gas-liquid chromatography. Appl. Microbiol., 13, 22-27 (1965).

23) Paynter, M. J. B. and Hungate, R. E., Characterization of Methanobacterium mobilis, sp. n., isolated from the bovine rumen. J. Bacteriol., 95, 1943-1951 (1968).

24) Rode, L. M., Cheng, K. J., and Costerton, J. W., Digestion by cattle of urea-treated, ammoniatreated, or rolled high-moisture barley. Can. J. Anim. Sci., 66, 711-721 (1986).

25) Scott, H. W. and Dehority, B. A., Vitamin requirements of several cellulolytic rumen bacteria. $J$. Bacteriol., 89, 1169-1175 (1965).

26) Sneath, P. H. A., Mair, N. S., Sharpe, M. E., and Holt, J. G., Bergey's Manual of Systematic Bacteriology, Vol. 2, The Williams and Wilkins Co., Baltimore (1986), p. 999-1434.

27) Theander, O., Hartley, R. D., and Stewart, C. S., A note on the OECD collaborative experiment on ammonia-treated straw. Anim. Feed Sci. Technol., 10, 89-91 (1984).

28) Waagepetersen, J. and Thomsen, K. V., Effect on digestibility and nitrogen content of barley straw of different ammonia treatments. Anim. Feed Sci. Technol., 2, 131-142 (1977). 